\title{
PARASITOIDS ATTACKING AONIDIELLA AURANTII (MASKELL) (HOMOPTERA: DIASPIDIDAE) WITH EMPHASIS ON PARASITOID FAUNA OF THIS SPECIES IN BAHARIA OASIS
}

\author{
SHAABAN ABD-RABOU
}

Plant Protection Research Institute, ARC, Dokki, Giza

(Manuscript received 26 February 2009)

\begin{abstract}
During the present work, samples of different host plants heavily infested by red scale insect Aonidiella aurantii (Maskell) (Homoptera: Diaspididae) and associated with the parasitoid species at different locations in Egypt during 2004-2008 were collected. Preservation, isolation and identification of the parasitoids were conducted The results indicated that, thirteen species were recorded in Egypt. This work also includes red scale parasitoids survey in Baharia Oasis. Key to the parasitoids of $A$. aurantii and key to the genus Comperiella (Hymenoptera: Encyrtidae) from Egypt are included.
\end{abstract}

\section{INTRODUCTION}

Organophosphorus insecticides have been used commercially for the control of scale insects in Egypt throughout many years (Coll and Abd-Rabou,1998). Red scale Aonidiella aurantii (Maskell) ) (Homoptera: Diaspididae) is a serious pest on different economic crops (Miller and Kosztarab, 1979). The main injury caused by this insect is the ingestion of plant sap. Severely infested plants grow poorly and may drop leaves prematurely and suffer dieback of twigs and branches. The parasitoids of $A$. aurantii have been attracted many authors, El-Minshawy and Osman, 1974, Moursi and Mesbah, 1985; Abd-Rabou ,1997 , Abd-Rabou ,1999a and Abd-Rabou ,1999b and recently by Abd-Rabou and Attia (2006).

The present work dealt with the parasitoids of $A$. aurantii with emphasis on parasitoids of this species in Baharia Oasis.

\section{MATERIALS AND METHODS}

During 2004-2008, leaves and twigs heavily infested by red scale, A. aurantii in different parts of Egypt were collected and transferred to the laboratory for parasitoids emergence and identification. Identification of the parasitoid followed mounting the specimens through the method of Noyes (1982). Identification of the parasitoid followed by the keys of Prinsloo (1996) and Abd-Rabou (1999 a,b ). The collection also was conducted in all locations in Baharia Oasis. 


\section{RESULTS AND DISCUSSION}

\section{List of parasitoids attacking Aonidiella aurantii}

This list includes thirteen species of parasitoids, 12 species belonging to family Aphelinidae and one species from Family Encyrtidae.

\section{Family: Aphelinidae}

\section{Aphytis africanus Quednau}

Material examined: 5 $q+, 6 \hat{\jmath} \widehat{\partial}$, El-Minya 25.IV. 2003 ex. Aonidiella aurantii (Maskell).

Remarks: Abd-Rabou and Hayat (2003) collected this species for the first time in Egypt.

\section{A. azai Abd-Rabou}

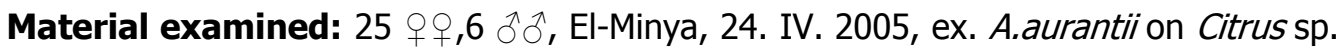
Remarks: Abd-Rabou (2004a) collected this species for the first time in Egypt.

\section{A. chrysomphali (Mercet)}

Material examined:, 15 우, Gharbiya, 20.IX.2006, ex. A. aurantii on F. nitida.

Remarks: This species was recorded for the first time in Egypt by Abd-Rabou and Hayat (2003).

\section{A. coheni DeBach}

Material examined: 7우, El-Arish (North Sinai), 25. X.2006, ex. A. aurantii on $F$. nitida.

Remarks: This species was recorded for the first time in Egypt by Hafez (1988).

\section{A. lingnanensis Comepre}

Material examined: 7 아, Behira, 11.X. 2007 ex. A. aurantii on Citrus sp.

Remarks: Hafez (1988) recorded this species as the most common species of $A$. aurantii on Citrus sp.

\section{A. sinaii Abd-Rabou}

Material examined: 13 $+q, 4 \hat{\partial} \hat{\partial}$, South Sinai, $15 . X 2008$ ex. $A$. aurantii on $F$. nitida.

Remarks: This species was recorded for the first time in Egypt by Abd-Rabou (2004b). 


\section{Coccobius sp}

Material examined: $2 \circ$ 으, El-Minya, 15.III.2006 ex. A. aurantii. On citrus (PPRI).

Remarks: This species was recorded for the first time in Egypt, associated with $A$. aurantii by Abd-Rabou (1999 a).

\section{Encarsia aurantii (Howard)}

Material examined: 3 우, Marsa Matruh , 13.X. 2004, ex. A. aurantii on Ficus nitida.

Remarks: This species was recorded for the first time in Egypt by Hafez (1988).

\section{E. citrina (Craw)}

Material examined: 5 우, North Sinai (El-Arish), 23. X. 2008, ex. A. aurantii, on Citrus sp.

Remarks: This species was recorded for the first time in Egypt by Priesner \& Hosny (1940).

\section{E. lounsburyi (Berlese \& Paoli)}

Material examined: 15 아, Beni-Suef, 14. XI. 2007, ex. A. aurantii on Citrus sp.

Remarks: This was recorded for the first time in Egypt by Priesner \& Hosny (1940)..

\section{Marietta leopardina Motschulsky}

Material examined: 9 우, Ismailia, 17. VI. 2000, ex. A. aurantii on F.nitida.

Remarks: This species was recorded for the first time in Egypt by Priesner and Hosny (1940).

\section{M.picta (Andre)}

Material examined: $8 \uparrow q$, Alexandria , 2. V. 2008, ex. $A$. aurantii on Citrus sp.

Remarks: This species was recorded for the first time in Egypt as a hyperparasitoids associated with $A$. aurantii by Abd- Rabou (1999a).Later , Abd-Rabou(2001) also recorded this hyperparasitoid species.

\section{Family: Encyrtidae}

13. Habrolepis aspidioti Compere \& Annecke

Material examined: $12 \widehat{\partial} \widehat{\partial}$, Minyufiya, 29. VIII. 2004, ex. A. aurantii on Citrus sp.

Remarks: This species was recorded for the first time in Egypt by Priesner and Hosny (1940).

\section{Key to the parasitoids of Aonidiella aurantii}

This key includes thirteen species of $A$. aurantii parasitoids. These are : Family: Aphelinidae. A. africanus, A. azai, A. chrysomphali , A. coheni ,A. lingnanensis, A. 
sinaii , Coccobius sp., Encarsia aurantii , E. citrina , E. lounsburyi , M. leopardina, M.picta. Family: Encyrtidae. Habrolepis aspidioti .

\section{Key to species modified and Adopted from Abd-Rabou( 1999b)}

1.Often less than $1 \mathrm{~mm}$. in length, antennae usually with three to eight segments, rarely with nine, mesoscutum with parapsidal sulci always developed, fore wing with marginal vein extremely long, ovipositor never protruding strongly...... 2

- Often 0.5-6 mm. in length, antennae with five to twelve segments, mesoscutum with parapsidal sulci seldom developed, fore wing with marginal vein relatively short, ovipositor rarely protruding strongly caudally, male funicle two segmented

Habrolepis aspidioti

2.1. Antennae 7-9 segmented, fore wing without linea calva ..................................3

- Antennae 4-6 segmented, fore wing generally with linea calva ............................6

3.2. Antennae 7-segmented, if antennal formula $1,1,3,2$; then either fore wing with linea calva or axillae very small, not projecting forewards Antennal formula 1,2,3,2; propodeum not distinctly longer than metanotum; mesoscutum with numerous setae; submarginal vein with 4 or more setae.

Coccobius sp.

- Antennae 8 or 9 -segmented, if 7 -segmented then not with the formula $1,1,4,1$; linea calva absent and axillae large, strongly projecting forewords.

4.3. Stigmal vein of fore wing with an evident asetose area proximally

Encarsia aurantii

- Stigmal vein of fore wing without an evident asetose area proximally. At least one small seta proximal to the stigmal vein

5.4.Submarginal vein of fore wing with one seta. Encarsia lounsburyi

- Submarginal vein of fore wing with two setae. Encarsia citrina

6.2. Propodeum short, subequal to metanotum, without crenulae. 7

- Propodeum long, considerably longer than metanotum, bearing marginal crenulae. 8

7.6. Antennal scape nearly twice as long as wide, with 2 oblique fuscous bands; fore wing boord, less than twice as long as wide with a slightly different pattern. Marietta picta -Antennal scape twice as long as wide, with a single band; fore wing narrow, not less than twice as long as wide, with pattern Apex of fore wing without infuscate band in middle, mesoscutum 4 setae Marietta leopardina

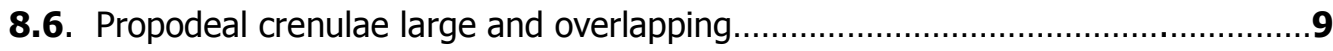

-Propodeal crenulae (large or small) non-overlapping..... 
9.8. Club shorter, less than $3 x$ as long as broad; ovipositor sheaths about $0.4 x$ of mid tibia; (Propodeal crenulae relatively smaller, less elongate and more oblique.

- Club about $3 x$ as long as broad; ovipositor sheaths about $0.5 x$ of mid tibia 10

10.9. Thoracic sterna immaculate, club 3.1. times as long as wide. Aphytis azai - Thoracic sterna dusky 11

11. 10.Body setae slender and pale; mid lobe usually with $10-12$ setae; fore wing proximad of linea calva with 30-50 setae Aphytis lingnanensis

- Body setae relatively coarser and darker; mid lobe with 12-14 setae; fore wing proximad of linea calva with 50-70 setae. Aphytis coheni

12.8. Propodeum $6-8 \mathrm{x}$ as long as metanotum. Aphytis chrysomphali -Propodeum short, less than $4 \mathrm{x}$ as long as metanotum Aphytis sinaii

\section{Parasitoids attacking Aonidiella aurantii in Baharia Oasis:}

Results indicated that the only parasitoid species collected from Markaz Bawiti in Baharia Oasis ( Fig.1) was Comperiella lemniscata Compere \& Annecke (Hymenoptera: Encyrtidae).

Material examined: 25 우, Baharia Oasis (Bawiti ), VII. 2008, ex. A. aurantii on Ficus nitida

Remarks: This species was recorded for the first time in Egypt as a parasitoid associated with $A$. aurantii by Abd-Rabou and Attia (2006).

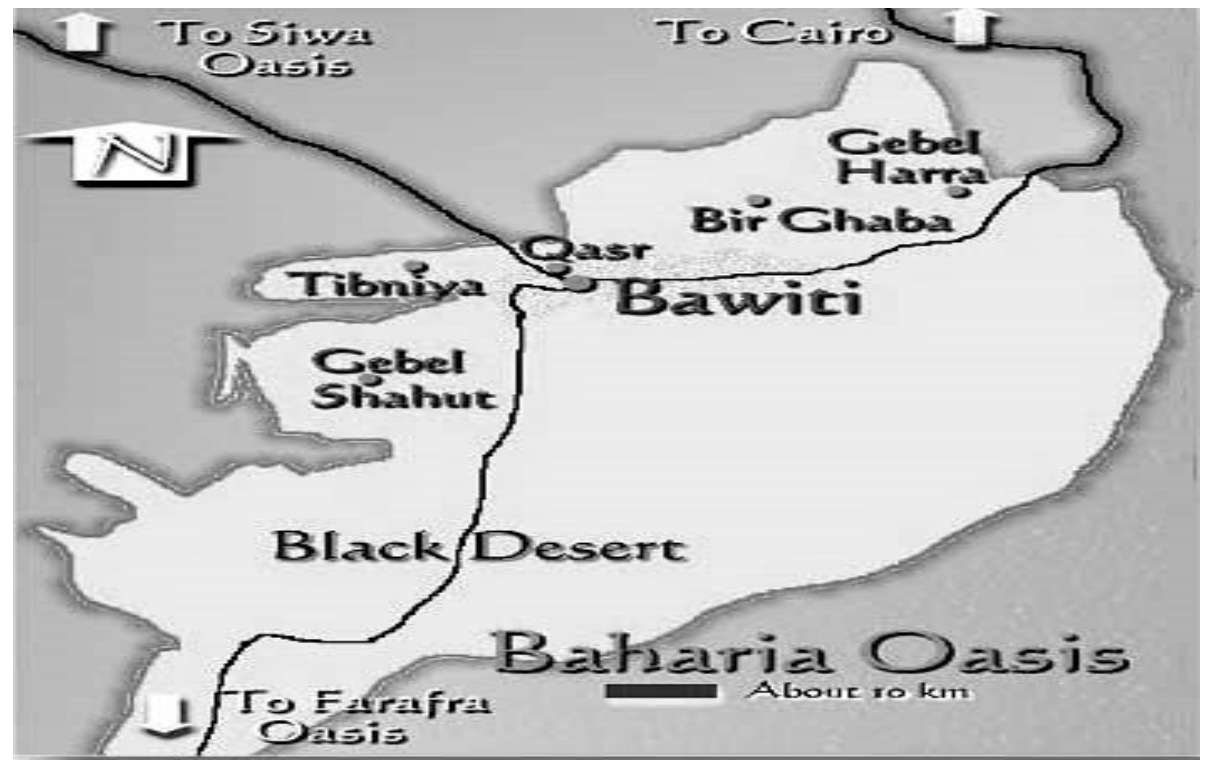

Fig. 1. Map Baharia Oasis adopted from www.egyptmyway.com/contactforms.html (2008). 


\section{Key to Genus Comperiella Howard in Egypt}

This key includes two species of Genus Comperiella. These are : Comperiella bifasciata Howard and C. lemniscata Compere \& Annecke .

\section{KEY TO SPECIES}

1. Lateral ocelli one ocellus diameter apart and tibial spur of middle leg subequal to basitarsus Comperiella lemniscata

-Lateral ocelli two ocellar diameters apart and tibial spur of middle leg distinctly longer than basitarsus

Comperiella bifasciata

\section{REFERENCES}

1. Abd-Rabou, S. 1997. Parasitoids attacking some species of scale insects (Homoptera: Coccoidea: Diaspididae) in Egypt. Proceeding of the First Scientific Conference of Agricultural Sciences, Faculty of Agric. Assiut Univ., Vol. II, 727736.

2. Abd-Rabou, S. 1999a. Parasitoids attacking the Egyptian species of armored scale insects (Homoptera : Diaspipidae). Egypt J. Agric. Res., 77(3): 1113-1129.

3. Abd-Rabou, S. 1999b. An annotated list of diaspidid parasitoids in Egypt. Entomolgica, Bari, 33: 173-177 .

4. Abd-Rabou, S. 2001. Key to the genrea of Encyrtidae from Egypt (Hymenoptera : Chalcidoidae: Encyrtidae) J. Agric. Res. 79 (1): 79-87.

5. Abd-Rabou, S. 2004a. Revision of the genus Aphytis (Aphelinidae: Hymenoptera) with discriptions of two new species from Egypt. Entomologia Sinica, Vol.11(2):149-164.

6. Abd-Rabou, S. 2004b. First record of some hymenopterous parasitoids of whiteflies, scale insects and leaf miners in Egypt with description of Aphytis sinaii (n. sp.). Egypt. J. Agric. Res.82( 3): 1089-1098.

7. Abd-Rabou, S. and M. Hayat. 2003. A synopsis and key to the Egyptian species of Aphytis Howard (Hymenoptera : Aphelinidae) parasitoids of diaspidid scale insects (Homoptera : Diaspididae). Acta Phytopathologica et Entomologica Hungarica, Vol. 38(3-4):357-363.

8. Abd-Rabou S. and A. R. Attia. 2006. New record of the parasitoid, Comperiella lemniscata Compere and Annecke (Hymenoptera: Encyrtidae) on Aonidiella aurantii (Homoptera: Diaspididae) on guava in Egypt. Egypt. J. Agric.Res.84 (1): 83-87. 
9. Coll, M. and S. Abd-Rabou. 1998. Effect of oil emulsion sprays on parasitoids of the black parlatoria, Parlatoria ziziphi, in grapefruit. Biocontrol, 43: 29-37.

10. El-Minshawy, A. M. and O. A. Osman. 1974. Biological and ecological studies on the masked scale insect, Mycetaspis personata (Costock) in Alexandria area (Coccoidea : Diaspididae). Bull. Lab. Ento. Ag., P. 31: 152-172.

11. Hafez, M. 1988. Population fluctuations on parasites of California red scale, Aonidiella aurantii (Mask) (Homoptera : Diaspididae) in Alexandria. J. App. Ent., 106 (2): 183-187.

12. Miller, D. R. and M. Kosztarab. 1979. Recent advances in the study of scale insects. Annual Review of Entomology, 24: 1-27.

13. Moursi, K. S. and H. A. Mesbah. 1985. Olive pests irrigated-farm system in the Egyptian western desert, with special references to armored scale insects. Ann. Agric. Sci. Moshtohor, 23 (2): 901-911.

14. Noyes, J. S. and M. Hayat. 1994. Oriental mealybug parasitoids of the Anagyrini(Hymenoptera: Encyrtidae). C. A. B. International, Wallingford.

15. Prinsloo, G. L. 1996. The genus Comperiella (Hymenoptera : Encyrtidae) in southern Africa: parasitoids of armoured scale insects ( Homoptera : Diaspididae). African Entomology, 4(2): 153-160.

16. Priesner, A. and M. Hosny. 1940. Notes on parasites and predators of Coccidae and Aleyrodidae in Egypt. Bull. Soc. Ent. Egypte, 24: 58-70.

17. Web site 2008. www.egyptmyway.com/contactforms.html . 


\section{طفيليات الحشرة القشرية الحمراء مع التركيز على طفيلياتها \\ فى الواحات البحرية}

\section{شعبان عبدريه}

معرة بحوث وقاية النباتات - مركز البحوث الزراعبة - دقي - جيزة

تضمن هذا العمل تجميع عينات مصابة بالحشرة القترية الحمراءو منطفل عليها فى آماكن

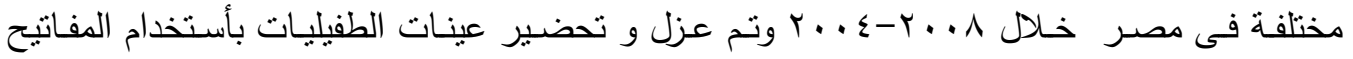
التصنيفية المتخصصـة لتعريف الطفيليات. أتضـح من نتائج التعريف أن هذه الآفة منطفل عليها با طفيل . هذا العمل تضمن أيضـا حصر لطفيليات هذه الآفة فى الواحات البحريـة ـ تم عمل مفتاح تصنيفى لطفيليات هذه الآفة و مفتاح تصنيفى لجنس كومبريلا فى مصر • 